Tjalling C. Koopmans Research Institute Tplligl Aoopman

Discussion Paper Series nr: 12-11

\title{
Entrepreneurship, Know ledge, Space, and Place: Evolutionary Economic Geography meets Austrian Economics
}

Erik Stam

Jan Lambooy 


\section{Tjalling C. Koopmans Research Institute \\ Utrecht School of Economics \\ Utrecht University}

Kriekenpitplein 21-22

3584 EC Utrecht

The Netherlands

telephone $\quad+31302539800$

fax +31302537373

website www.koopmansinstitute.uu.nl

The Tjalling C. Koopmans Institute is the research institute and research school of Utrecht School of Economics.

It was founded in 2003, and named after Professor Tjalling C. Koopmans, Dutch-born Nobel Prize laureate in economics of 1975.

In the discussion papers series the Koopmans Institute publishes results of ongoing research for early dissemination of research results, and to enhance discussion with colleagues.

Please send any comments and suggestions on the Koopmans institute, or this series to J.M.vanDort@uu.nl

ontwerp voorblad: WRIK Utrecht

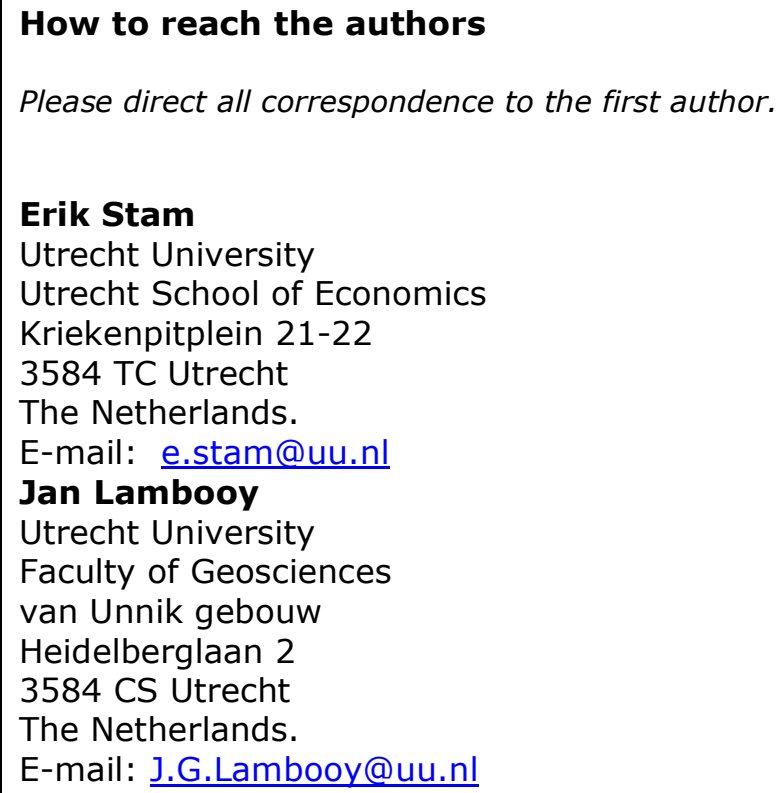




\title{
Entrepreneurship, Knowledge, Space, and Place: Evolutionary Economic Geography meets Austrian Economics
}

\author{
Erik Stama \\ Jan Lambooy ${ }^{b}$ \\ aUtrecht School of Economics \\ Utrecht University \\ ${ }^{b}$ Faculty of Geosciences \\ Utrecht University
}

August 2012

\begin{abstract}
In this paper we investigate the spatial aspects of the conditions of entrepreneurship on the one hand, and the consequences of entrepreneurship on the other hand. The consequences are the effects of individual interactions that may lead to the emergence of complex systems that are largely the "result of human action, but not of human design" (Hayek, 1967). These emergent systems have spatial coordinates and localized effects on the growth of knowledge and economic activity. The emergent systems-new organizations, institutions, industrial clusters, cities, and regions-in turn form the context for subsequent entrepreneurial actions.

We show the strengths and opportunities of Austrian economics for the indeterminate dynamic analysis of entrepreneurship and evolving selection environments, and the spatial aspects of these processes and structures. We explicitly investigate the bridge between evolutionary economic geography and Austrian economics.

The paper is structured as follows: in the second section, we introduce Austrian as well as evolutionary geographic treatments of entrepreneurship. In the third section we investigate entrepreneurship and its conditions of space and place. In the fourth section, we elaborate on the urban aspects of the conditions of entrepreneurship as it is approached in evolutionary theories. The fifth section centers on the spatial aspects of the consequences of entrepreneurship, with a particular focus on its impact on urban and regional development.
\end{abstract}

Keywords: entrepreneurship, space, place, evolutionary economic geography, Austrian economics, regional development

JEL classification: B52; B53; L26; M13; R11 


\section{ENTREPRENEURSHIP, KNOWLEDGE, SPACE,}

\section{AND PLACE: EVOLUTIONARY ECONOMIC GEOGRAPHY MEETS AUSTRIAN ECONOMICS}

What would we learn from bringing together Austrian economics and evolutionary economic geography? In this paper we argue that these approaches are very complementary and commensurable. We will investigate the spatial aspects of the conditions of entrepreneurship on the one hand, and the consequences of entrepreneurship on the other hand. The consequences are the effects of individual interactions that may lead to the emergence of complex systems that are largely the "result of human action, but not of human design" (Hayek, 1967). These emergent systems have spatial coordinates and localized effects on the growth of knowledge and economic activity. The emergent systems-new organizations, institutions, industrial clusters, cities, and regions-in turn form the context for subsequent entrepreneurial actions.

In this paper we will show the strengths and opportunities of Austrian economics for the indeterminate dynamic analysis of entrepreneurship and evolving selection environments, and the spatial aspects of these processes and structures. We will explicitly investigate the bridge between evolutionary economic geography (Boschma and Lambooy, 1999; Boschma and Frenken, 2006; Boschma and Martin, 2010) and Austrian economics. The paper is structured as follows: in the second section, we introduce Austrian as well as evolutionary geographic treatments of entrepreneurship. In the third section we investigate entrepreneurship and its conditions of space and place. In the fourth section, we elaborate on the urban aspects 
of the conditions of entrepreneurship as it is approached in evolutionary theories. The fifth section centers on the spatial aspects of the consequences of entrepreneurship, with a particular focus on its impact on urban and regional development.

\section{AUSTRIAN ECONOMICS AND EVOLUTIONARY ECONOMIC GEOGRAPHY}

\section{Entrepreneurship and geography in Austrian economics}

In a society with dispersed knowledge, entrepreneurs have to identify opportunities, recognize them as relevant, and match them with (demand) preferences, technological feasibilities, and their own skills. According to Austrian theory, this is done on a subjective basis: different people not only have different preferences but also different perceptions, interpretations, and understandings of values and feasibilities, which they adapt in mutual interaction and communication in specific contexts over their unique life courses (Nooteboom, 2000). Different minds think different things (Lachmann, 1978), and the entrepreneurial opportunities people perceive very much depend on their prior knowledge (Shane, 2000).

Hayek (1945) teaches us that there is no "God-like view" of society from which any single individual could fully know the preferences and available means of others. This knowledge is dispersed among all the individual members of a society. Hayek (1945) makes a distinction between scientific knowledge-knowledge of general rules by experts - and local (or practical) knowledge, with the latter being knowledge of particular circumstances of time and place. This implicitly brings geography—that is, places_-into the Austrian framework (see also Desrochers, 1998; Heijman and Leen, 2004; Andersson, 2005). 
Practically every individual has some advantage over all others. Each individual has this advantage since she possesses unique information which she might use in beneficial ways. However, the beneficial use of the information requires either that the decisions are left to the individual with the unique information or that the decisions are made with her cooperation (cf. Shane, 2000, on prior knowledge). The knowledge of the particular circumstances of time and place is a key input in the entrepreneurial process, and provides the bridge from general scientific knowledge to useful applications in particular contexts. Hayek (1945) shows that the success of the market comes from its effectiveness in bringing private and local knowledge into use, as opposed to scientific knowledge. Hayek's argument resembles the more recent knowledge-spillover theory of entrepreneurship (Audretsch et al., 2006), in which entrepreneurs are seen as the agents that turn scientific knowledge into knowledge that can be used in daily practice (and introduced in and diffused through the market).

This knowledge of particular circumstances of time and place is even more important because of the continuous changes that affect the stock of scientific knowledge; knowledge about its practical applications; and local circumstances—-that is, the restless nature of capitalism (Metcalfe, 2002). In the 1930s, Hayek emphasized information as a basic element in the price system as well as for understanding economic development. Later, he developed this concept further into the wider one of knowledge (Hayek, 1945).

The entrepreneurial discovery approach is central to the Austrian tradition (Kirzner, 1997). Key elements are the role of knowledge and entrepreneurial discovery in the process of market equilibration: "the systemic process in which market participants acquire more and more accurate and complete mutual knowledge of potential demand and supply attitudes" (Kirzner, 1997, p. 62), which reduces the 
sheer (that is, unknown) ignorance of market participants. Entrepreneurial discovery ${ }^{1}$ involves a type of alert entrepreneurial choice in which imagination and boldness play central roles. Entrepreneurs thus discover-by surprise-innovations in an openended uncertain world (Knight, 1921). ${ }^{2}$

This process is not without preconditions: rivalrous competition is needed. This competition serves the twin purpose of offering the best possible deals to consumers (the traditional interpretation of market competition), and of revealing information to market participants. The information is such that no one had previously been aware that they lacked it (see Hayek, 1978, p. 179 on competition as a discovery procedure). In this information-revealing sense, entrepreneurial discovery can be compared with the Popperian approach to scientific progress. Entrepreneurship, like science, is a problem-solving activity in which competing solutions to a problem are generated. Each solution is a guess; a conjecture: experiments and trial-and-error processes will reveal which of the proposed solutions solves the problem best. In this process it is also possible that the problem should be redefined, or that underlying problems are revealed. Harper $(1996 ; 1998)$ suggests that the entrepreneurial process is similar to the scientific process of conjecture and refutation: alert entrepreneurs discover an opportunity to create value in the market; however, this conjecture needs to be tested in the market. Through the market test the entrepreneur will learn whether the opportunity is really valuable, and the entrepreneur might amend his conjecture. This process of trial-and-error may be repeated many times, and delivers knowledge not only to the entrepreneur, but also other market actors, including emulators and new competitors.

Austrians also focus on the importance of institutions in economic life. Two aspects stand out regarding institutions and entrepreneurship. First, the role of 
institutions in securing social order by providing certainty and shared expectations in social interactions, which thereby enable the individual to concentrate on innovative actions that are inherently full of uncertainty. Examples of key institutions in this respect are the rule of law and property-right regimes. The second aspect concerns the role of institutions in the allocation of talent in general (cf. Murphy et al., 1991; Acemoglu, 1995), and entrepreneurial efforts in particular (Baumol, 1990). Austrian economic theory includes the assumption that entrepreneurship is an omnipresent aspect of human action. If every context for action is to some degree novel, people have to improvise - if ever so slightly—in all of their behavior (Koppl, 2007). To improvise is to do something in a new and different way-in other words, innovators are improvisers. This omnipresent "innovation" makes entrepreneurship an aspect of all human action. ${ }^{3}$

If one assumes that entrepreneurship is an omnipresent aspect of human action, it cannot be the "cause" of economic development as such (Boettke and Coyne, 2003): the rules of the game determine the pay-offs of different types of entrepreneurship, and in that way guide entrepreneurial action in more or less productive directions. ${ }^{4}$ Institutions are thus seen both as a fundamental precondition for entrepreneurial action to take place, and as the rules that affect the allocation of entrepreneurial talent (see Table 5.1). These institutions are often created in particular places, and their effects are often limited to certain—spatially confined—groups. 
Table 5.1: Entrepreneurship and geography in Austrian economics

\begin{tabular}{|l|l|l|}
\hline \multicolumn{1}{|c|}{ Key concept } & \multicolumn{1}{|c|}{ Source } & \multicolumn{1}{c|}{ Effect } \\
\hline Prior knowledge & $\begin{array}{l}\text { Individual biographies } \\
\text { (spatiotemporally specific) }\end{array}$ & $\begin{array}{l}\text { Directs entrepreneurship; } \\
\text { transforms scientific } \\
\text { knowledge into practical } \\
\text { knowledge }\end{array}$ \\
\hline $\begin{array}{l}\text { Entrepreneurial } \\
\text { discovery }\end{array}$ & $\begin{array}{l}\text { Rivalrous competition of } \\
\text { potential solutions }\end{array}$ & $\begin{array}{l}\text { Creates novel knowledge / } \\
\text { reduces ignorance }\end{array}$ \\
\hline Institutions & $\begin{array}{l}\text { Unintended effect of human } \\
\text { action }\end{array}$ & $\begin{array}{l}\text { 1) Provides certainty that } \\
\text { enables focused innovation; } \\
\text { 2) allocates entrepreneurship }\end{array}$ \\
\hline
\end{tabular}

\section{Entrepreneurship in evolutionary economic geography}

Entrepreneurship is a fundamental driver of economic evolution. Evolutionary approaches emphasize differentiation, unexpected situations, and continuous change in external conditions and in the composition of elements. Entrepreneurs can be seen as the key actors to optimally benefit from new unexpected opportunities. Entrepreneurship is also a distinctly spatially uneven process, and thus an important explanation of the uneven economic development of regions and nations. Not surprisingly, entrepreneurship is a key element in evolutionary economics (Schumpeter, 1934; Witt, 1998; Grebel et al., 2003; Metcalfe, 2004) and has been recognized as an important factor in explanations of (regional) economic development (Acs and Armington, 2004; Audretsch et al., 2006; Fritsch, 2008).

This means that the explanation of regional variations in entrepreneurship has become an important issue, which is not surprising since there are pronounced differences within and between nations in rates of entrepreneurship and in their determinants (Reynolds et al., 1994; Stam, 2005; Bosma and Schutjens, 2008). These differences tend to be persistent over time, reflecting path dependence in industry structure (Brenner and Fornahl, 2008), formal institutions (Casper, 2007), and culture 
(Beugelsdijk, 2007; Gianetti and Simonov, 2009; Saxenian, 1994). Such regional attributes vary widely across regions, but are relatively inert over time. Next to path dependence, cumulative causation also magnifies spatial differences in entrepreneurship: the pursuit of entrepreneurial opportunities feeds further opportunities (Holcombe, 2007). First, any change by one entrepreneur alters the economic environment and provides opportunities for additional adjustments by other entrepreneurs. Second, entrepreneurial activity is likely to create wealth and in that way increases demand and the extent of the market. Third, the creation of market niches that did not previously exist provides opportunities for new entrepreneurs to enter and expand this market niche. Entrepreneurial opportunities thus come into being because of prior acts of entrepreneurship (cf. Metcalfe, 2002 on the growth of knowledge). Holcombe (2007, p. 61) writes that "Bill Gates could not have made his fortune had not Steve Jobs seen the opportunity to build and sell computers, and Steve Jobs could not have built a personal computer had not Gordon Moore invented the microprocessor." Historical processes produce uneven spatial economic patterns of both the characteristics of individuals and the "availability" of opportunities, that taken together conditions but does not determine economic behavior (Boschma and Frenken, 2006; Lambooy, 2010 b), of which entrepreneurship is a special class.

Next to the creation and diffusion of entrepreneurial opportunities, selection plays an important role in entrepreneurship, reflected in the fact that most new firms do not survive for very long, as well as in the fact that few firms (often less than one out of ten start-ups) attain substantial growth (Reynolds and White, 1997; Stam and Wennberg, 2009). Selection is generated by the decisions of external resource holders to allocate their resources among these firms (Aldrich, 1999; Baum and Silverman, 2004). 
New firm formation is affected by different selection environments. Most directly there is competition in product markets: a lack of competition may either indicate an opportunity (a gap to be filled) or a constraint (high entry barriers). Fierce competition forces firms to produce and sell efficiently, if they are to survive. For new firms that need to reach a substantial size, selection in the capital and labor markets are also important. Such firms need to attract financial and human resources in competition with other organizations that also need these resources in the face of limited supply. Competition is often a very local process: more distant firms are less likely to compete for the same pool of human resources or product markets than firms in spatial proximity (Cattani et al., 2003; Baum and Mezias, 1992; Sorenson and Audia, 2000). Another aspect of the selection environment is the size and the nature of local demand; however, entrepreneurs can also extend external trade relations and gain increasing returns in the value chain (Young, 1928; Chandra and Sandilands, 2005). Table 5.2 gives a summary of the treatment of entrepreneurship in evolutionary economic geography.

Table 5.2: Entrepreneurship in evolutionary economic geography

\begin{tabular}{|l|l|l|}
\hline \multicolumn{1}{|c|}{ Key concept } & \multicolumn{1}{|c|}{ Source } & \multicolumn{1}{c|}{ Effect } \\
\hline $\begin{array}{l}\text { Spatiotemporal } \\
\text { heterogeneity }\end{array}$ & $\begin{array}{l}\text { Regional variety in } \\
\text { entrepreneurial action and } \\
\text { path dependence in } \\
\text { structures }\end{array}$ & $\begin{array}{l}\text { Causes diverging rates of } \\
\text { entrepreneurship and of } \\
\text { economic growth }\end{array}$ \\
\hline Regional path dependence & $\begin{array}{l}\text { Stickiness of industry- } \\
\text { specific investments (in } \\
\text { tangible and intangible } \\
\text { resources), institutions, } \\
\text { and culture }\end{array}$ & $\begin{array}{l}\text { Generates continuity in } \\
\text { entrepreneurship rates and } \\
\text { direction (industrial } \\
\text { structure) over time }\end{array}$ \\
\hline Selection environment & $\begin{array}{l}\text { Markets (resource } \\
\text { munificence and } \\
\text { competition); institutions }\end{array}$ & $\begin{array}{l}\text { 1) Productivity of firms; } \\
\text { 2) choice of particular } \\
\text { governance form }\end{array}$ \\
\hline
\end{tabular}


Austrian economic theories provide useful theories that deal with entrepreneurship and the market process that implicitly take into account the spatial aspects of (practical) knowledge and institutions. Evolutionary economic geography, on the

other hand, provides useful insights into the causes of uneven economic development over space and time, while only implicitly taking account of the role of entrepreneurs and markets as agents and outcomes of evolutionary processes.

\section{THE BIOGRAPHY OF ENTREPRENEURS IN SPACE}

Different people not only have different preferences but also different perceptions, interpretations, and understandings of values and feasibilities, which they adapt in mutual interaction and communication in specific contexts over their unique life histories. Different minds think different things (Lachmann, 1978), and the entrepreneurial opportunities people perceive very much depend on their prior knowledge (Shane, 2000). The biography of an entrepreneur provides her with accumulated knowledge about particular circumstances, especially knowledge about the spatial distribution of particular means and preferences. On the one hand entrepreneurs connect different "worlds," either literally (see Saxenian, 2006 on the "new Argonauts") or in a cognitive sense (see Nooteboom, 2000), and in this way make novel combinations. On the other hand, empirical studies have shown that entrepreneurs, just like other human beings, are relatively inert in a spatial sense: it is a stylized fact that entrepreneurs are most likely to start their firm in the region where they live and work (Stam, 2010).

For nascent entrepreneurs the focal choice concerns what kind of firm to start, given their location; the choice rarely concerns choosing a location for a given firm 
(Stam, 2007). The social ties of the potential entrepreneurs are likely to be localized, and induce entrepreneurs to start their firm in close spatial proximity to their homes and to their current employers (Cooper and Folta, 2000; Sorenson, 2003; Stam, 2007; Parwada, 2008). The fraction of entrepreneurs working in the region where they were born is significantly higher than the corresponding fraction for dependent workers (Michelacci and Silva, 2007). ${ }^{5}$ A study of Portuguese manufacturing firms found that entrepreneurs were willing to accept labor costs three times higher than in alternative locations to locate the new business in their current region (Figueiredo et al. 2002). A British study found that individuals are more likely to be self-employed if they have not moved regions recently (in the previous seven years; Blanchflower and Oswald 1990). A recent Danish study (Dahl and Sorenson 2011) found that firms perform better-they survive longer and generate greater annual profits and cash flows-when they are located in regions in which their founders have lived longer. This effect appears substantial, similar in size to the value of prior experience in the industry (that is, the value of being a spin-off).

This locational stickiness is quite a sharp contrast to the modern-day phenomenon of entrepreneurs leaving their country of origin (especially India and China), and, like "argonauts," roaming the world in search of opportunities (Saxenian, 2006). This kind of mobility of (migrant) entrepreneurs has been documented for centuries (see, for example, Swedberg, 2000), but is unlikely to represent a substantial part of the total population of entrepreneurs (yet?).

\section{The growth of knowledge}

New knowledge created at universities and research centers generates opportunities for entrepreneurship, especially in high-technology industries. Often such 
organizations are not able to fully recognize and appropriate the ensuing opportunities to commercialize their knowledge. Knowledge workers in such organizations respond to the opportunities that this type of new knowledge generates by starting new firms. In this way, they can appropriate the expected value of their endowment of knowledge (Acs et al., 2009; Audretsch et al., 2006; Zucker et al., 1998; Kirchhoff et al., 2007). ${ }^{6}$ Spatial proximity to these sources of new knowledge is an asset, if not a prerequisite, to entrepreneurial firms seeking to access and absorb spillovers from universities and research centers (Audretsch and Lehmann, 2005a; 2005b; Audretsch and Feldman, 1996; Audretsch and Stephan, 1996; Audretsch et al., 2005; Lambooy, 2010a). But spatial proximity is neither a sufficient nor a necessary condition. Having the ability to absorb knowledge is instead a necessary condition for using new knowledge that has been created by others (cf. Cohen and Levinthal, 1990), often in rather unexpected (to the inventor) ways (Shane, 2000). The creation of embodied knowledge, via education and learning-by-doing, takes several years (possibly at several locations).

The degree to which technological change promotes new firm formation (in high-technology industries) depends on various factors, with the institutional environment as a dominant condition. The institutional setting affects the nature of high-technology labor markets, venture capital markets, and the structure of buyersupplier ties. These markets and ties are highly relevant for the incentive and appropriability constraints that affect incumbent and start-up firms, respectively (Chesbrough, 1999; Casper, 2007). For example, institutions that support a fluid labor market, a well-developed venture capital market, and loose buyer-supplier ties allow new firms to rapidly assemble and deploy experienced engineering talent, and to move quickly to commercialize advanced technology. Cross-country research has shown that this situation is common in the United States, in contrast to Japan 
(Chesbrough, 1999). As another example, cross-regional research found that Silicon Valley was much more conducive to new technology-based firms than Route 128 (Massachusetts) for similar reasons (Saxenian, 1994; Kenney and Von Burg, 1999).

The institutional environment also affects the opportunity costs of leaving a (relatively secure) job at a university or research center for independent entrepreneurship (cf. Feldman, 2001). The institutional environment thus acts as a mediating factor between investments in the knowledge base of a society and the knowledge spillovers that entrepreneurs exploit.

\section{Spin-offs}

Although some individuals become successful entrepreneurs without related prior experience, they are the exception rather than the rule. Entrepreneurs are often organizational products, that is, they spin off a firm from their previous employer (Audia and Rider, 2005; 2006; Klepper, 2001). Far from being the universal choice, entrepreneurial action is relatively constrained: instead of looking around to seek the most profitable opportunity, the potential entrepreneur focuses his attention on a familiar industry. A person working in an industry is more likely to identify a market gap than a person without any industry experience (O'Farrell and Crouchly, 1984), irrespective of the degree of industry competition and growth prospects (Storey, 1982). Prior experience (Shane, 2000) and personal networks are likely to be acquired during the entrepreneur's career in existing organizations (Agarwal et al., 2004; Gompers et al., 2005; Klepper, 2001). The importance of this type of prior knowledge for the nature and performance of the new firm, in combination with the spatial inertia of firm founders, explain why the nature and number of organizations in a region are important determinants of entrepreneurship in a region. 
Klepper and colleagues (see Klepper, 2009; 2011) present a model in which spin-offs exploit knowledge from their parents. Firms are assumed to differ in terms of their initial competence at the time of entry, which shapes long-term performance. This competence is acquired from firms in related industries and from prior entrants in the same industry. The stock of incumbents and firms in related industries in a region determine the entry rate and post-entry performance of firms in a particular industry. Inter-regional differences in entry are not necessarily determined by localization economies - the presence of specialized suppliers, thick labor markets, or spillovers between firms. Spillovers are instead more likely to be within firms, with employees spinning out afterwards. The model is tested by using detailed data on entrants in multiple industries, varying from automobiles (Klepper, 2002; 2007; Boschma and Wenting, 2007), to semiconductors (Moore and Davis, 2004; Klepper, 2010), and fashion design (Wenting, 2008). Their findings support the basic premise of the model that spin-offs inherit knowledge from their parents, shaping their nature at birth and their survival chances.

\section{URBANIZATION AND ENTREPRENEURSHIP}

Cities have long been known to be society's predominant sites of innovation ${ }^{7}$ and wealth creation (see Hall, 1998), yet they are also its main source of negative externalities, such as crime, pollution, and disease (Bettencourt et al., 2007b). That urban areas are important for economic growth, because of agglomeration economies, is generally accepted. Labor productivity is higher in large agglomerations than elsewhere, but the explanations for this advantage are far from complete (Storper, 2011). Marshall (1890) and Jacobs $(1961 ; 1969)$ emphasize that the co-location of 
similar (Marshall) or differentiated and related (Jacobs) activities enable entrepreneurs to successfully start firms that benefit from the specific urban environment.

Urban regions are riddled with externalities, both negative and positive. Although externalities are considered to be "market failures" in neoclassical approaches, positive externalities can also be seen as opportunities for entrepreneurs to meet the "hidden demand." Agglomeration economies enable all kinds of entrepreneurs to start firms, who thereby benefit from externalities and increasing returns. On balance, urban areas are favorable places for entrepreneurship: population density has been found to positively affect entrepreneurship (Reynolds et al., 1994; Wagner and Sternberg, 2004). Some authors have argued that this positive effect of population density (most obvious in big cities) might be a temporary phenomenon: the resurgence of big cities in the 1990s is connected both to a reduction in negative social interactions such as crime and to an increase in positive social interaction (Glaeser and Gottlieb, 2006).

However, urbanization and its most straightforward indicators-population size and density—cover many mechanisms, which may have different weights and values in different contexts. This is for example reflected in the large differences in entrepreneurship rates between world cities (Acs et al., 2011). Advantages stemming from high population density include the relative ease of access to customers as well as to the inputs required (capital, labor, suppliers) to produce various goods and services. The classical "incubation hypothesis" in urban economics states that individuals aspiring to start small-scale production find themselves less obviously barred by a high cost structure at the center of an urban area than on the periphery (Hoover and Vernon, 1959, p. 47; Chinitz, 1961; Dumais et al., 1997). In addition, 
cities provide contexts in which serendipitous meetings are more likely to occur than in less densely populated areas (Jacobs 1969); these serendipitous meetings increase the likelihood of new opportunities and collaborations that might trigger the emergence of a new firm.

Urban density also improves the likelihood of getting into contact with highskilled individuals in the same or related knowledge domains: learning from higherskilled peers stimulates human capital accumulation in urban environments (Glaeser, 1999) and may lead to the creation and recognition of better-quality entrepreneurial opportunities. This human capital effect influences entrepreneurial opportunities and is strengthened by the relatively high concentration of universities and research centers in urban areas. Organizations that produce new scientific and technological knowledge have also been recognized as an important additional source of entrepreneurial opportunities (Audretsch et al., 2006; see also the sub-section headed "the growth of knowledge" above). The risks attached to starting a business in urban areas are also relatively low, due to relatively abundant employment opportunities that function as an occupational buffer for the entrepreneur if her firm fails.

Urban areas are often concentrations of educated individuals with business experience in their early and middle adult years, and in that way they constitute a source of entrepreneurs (Glaeser, 2007). Such areas also have important advantages regarding the demand that specialist entrepreneurs serve, as they contain sufficient demand for a rich variety of services and consumer goods (cf. Glaeser et al., 2000; Glaeser, 2007). Urbanization also positively affects diversification of consumer demand. This latter phenomenon is central in flexible specialization theory (Piore and Sabel, 1984), which explains such trends in terms of the breakup of the mass market for standardized goods and services and the consequent emergence of a variety of 
smaller niche markets that new or small firms may exploit. This diversification is, next to urbanization, also directly driven by the growth in overall demand.

\section{URBAN AND REGIONAL DEVELOPMENT}

In evolutionary approaches, differentiation and the emergence of new products and of new constellations of structural relations among agents, such as firms and end-users, are important elements. Novelty in economic and social structures and processes is related to heterogeneity and chance. The changes in quality that are associated with structural development make it necessary to investigate the process of selection. The role of agency and interactions with (evolving) selection environments are therefore emphasized. This agency is affected by and affects several ontological layers, ranging from the cognitive abilities of entrepreneurs to macro-economic and environmental shocks (see Fuller and Moran, 2001). Entrepreneurs are agents who are conditioned by, and sometimes change or even initiate, complex adaptive systems. These systems are situated in particular geographic contexts, and emerge, grow, and decline over time (cf. Fuller and Moran, 2001; Martin and Sunley, 2007).

Complex systems that are currently well-known because of their high levels of entrepreneurship, for example the high-technology clusters in Silicon Valley and around the University of Cambridge, are located in regions that were dominated by agriculture and exhibited low levels of entrepreneurship some decades ago. The supply of venture capital is created by co-evolutionary processes in which the emergence of entrepreneurial communities is strengthened (for example due to serial entrepreneurs who have sold their businesses and reinvest their money in new ventures as business angels or venture capitalists) by the development of a venture 
capital community. The latter community tends to follow the emergence of a cluster rather than the other way around (Feldman and Francis, 2003; Orsenigo, 2006; cf. Kreft and Sobel, 2005). In addition, the institutional infrastructure that supports entrepreneurship also often emerges as a product of a critical mass of entrepreneurship in a particular industry or set of related industries. The growth of these industries - by both the indigenous creation of new firms and the attraction of subsidiaries - is then reinforced by the institutional structure (Keeble et al., 1999; Garnsey and Heffernan, 2005).

These virtuous cycles of development can turn into vicious circles once congestion effects become stronger- to the extent that they are not offset by new agglomeration economies (Maggioni, 2006). The location patterns of "technological hotspots" (the main centers of dynamic technological developments) can shift over time. Many regions have tended to cling to their old established industries. Evolutionary economists call this "lock-in." The path dependency then reflects an old and formerly successful development path, even though the associated technologies, markets, and organizational structures have become obsolete. Completely deteriorated regions lack new technologies and new organizational structures and are thus technological "cold spots." Examples include the Ruhr area in Germany and Detroit in the United States.

This does not mean that it is impossible for lagging regions to regenerate and gradually build a new base with new technologies and production. One important barrier tends to be the lack of new entrepreneurs, since attitudes in lagging regions are often dominated by large corporations in cahoots with labor unions and regional governments. The old textile region of Manchester and the Ruhr area have shown that-although it takes time-new developments can evolve successfully, by the 
development of a new generation of entrepreneurs (Boschma and Lambooy, 2000). In such a dynamic approach a focus on industry structure is turned into a focus on industrial dynamics. The spatial concentration (or its absence) of an industry is not only an outcome of a process of industrial evolution, but also affects an industry's further evolution (Boschma and Frenken, 2006). This recursive relationship has, at the very least, three dimensions (Hannan et al., 1995; Stuart and Sorenson, 2003; Boschma and Wenting, 2007; Van Wissen, 2004). First, the spatial concentration of industrial activities can generate agglomeration economies that foster start-ups and innovation and, possibly, the birth of a related industry in the region. Second, geographic concentration of firms increases the level of competition and the exit of under-performing firms raises the average fitness of routines. Third, co-located firms can also facilitate successful collective action; initiatives are more likely to emerge among proximate agents that can more effectively control opportunistic behavior.

The location of both new and already existing firms is crucial for the development of regional and urban economies. The nature of their relations to one another and to consumers in regional markets is decisive for further developments, unless new technologies and new external conditions, for instance new export markets, can open new windows for development. To investigate urban and regional development it is necessary to investigate the nature of dynamic forces, such as knowledge, technology, and institutional structures (Boschma and Lambooy, 1999; Lambooy and Boschma, 2001; Boschma and Frenken, 2009). However, location can in its turn be a strong conditioning factor for the development of dynamic forces and growth, as is evident from the impact of region-specific institutional arrangements, distance costs, the advantages of proximity, and agglomeration advantages (Krugman, 1995; Lambooy, 1998; Klepper, 2010). Evolutionary economic geography 
emphasizes five groups of dynamic factors that affect the process of development and economic growth:

1. (technological) knowledge (or more broadly, formation of human capital, based on education, research, and experience from learning-by-doing); for instance technologies leading to much lower transport costs and improved communication;

2. impacts of technological developments on production and consumption systems;

3. the often unexpected results of creative economic actors (entrepreneurship and innovation);

4. the wide array of effects of agglomerations on human relations (networks), and on creativity and productivity, and;

5. in the longer run attention is also given to changing institutions (values, habits, laws, and rules).

Regional and urban development from this perspective of complexity and dynamism cannot be investigated as just quantitative development (economic growth). Instead, we need to study continuous changes in economic structure, production technologies, firms, organizations, governance, and behavior. Such an approach needs a different theory of growth than the neoclassical one. This can be based on Austrian and NeoSchumpeterian evolutionary theory. Although evolutionary approaches also focus on types of inputs and the structure of prices, their principal interest is in the interaction between technology, institutions, and heterogeneous organizations in the process of economic development. 
Evolutionary economic geography focuses on innovation, increasing variety, and increasing returns to scale, mostly with the firm as the unit of analysis. It supports the thesis of Jane Jacobs $(1969 ; 1984)$ and Alfred Marshall (1890) that increasing variation is the source of economic growth: "The tendency to variation is the chief cause of progress" (Marshall, 1890, p. 355; see also Cohen and Malerba, 2001). Although this view is too narrow to explain growth, it is still a good way to explain interregional differences in growth (Frenken and Boschma, 2007; Hidalgo and Hausmann. 2009). Another key issue in evolutionary economic geography is that if a certain level of human capital is concentrated in one place, it will generate more positive externalities (this kind of diffusion is also called "spillover benefits") than does the same level of human capital spread over different locations (Martin and Sunley, 1998).

In regions with diversified information fields, access to appropriate information and knowledge enhances the growth prospects of innovative firms. Many cumulative processes and feedback mechanisms explain the success of such regions. Spatial concentration results from an economic process that depends on the entrepreneurial function, which exploits (new) technologies (such as steam engines) and new kinds of organization (such as the headquarters of business services). This process can, of course, take many years to evolve into its eventual form (Hirooka, 2006).

\section{CONCLUSION}

In this paper we have argued that Austrian economics and evolutionary economic geography are both complementary and commensurable. They are complementary 
since key elements in Austrian economics_-such as entrepreneurial discovery, the market process, and institutions-have not received sufficient attention in evolutionary economic geography. Austrian economics leaves implicit the role of space and place, while spatially uneven economic activity, changing technological and spatial patterns, and economic development are all central in evolutionary economic geography. Evolutionary economic geography is commensurable with Austrian economics since it focuses on dynamics, (Knightian) uncertainty, bounded rationality, and rule-following (routines), and it is complementary to Austrian theories with its explicit analysis of the role of space and place.

In this paper we have investigated the spatial aspects of the conditions of entrepreneurship on the one hand, and the consequences of entrepreneurship on the other hand. These consequences are the effects of individual interactions that may lead to the emergence of complex systems, which have spatial coordinates and localized effects on the growth of knowledge and economic activity. These emergent systems-new organizations, institutions, cities, and regions-in turn form the context for subsequent entrepreneurial actions.

Evolutionary economic geography and Austrian economics provide key inputs for a new orthodoxy in economics, in which bounded rationality, rule-following, institutions, cognition, and evolution have moved to center stage (cf. Koppl, 2006). Together they provide a framework for understanding economic development as a bottom-up process, resulting in particular meso-structures that subsequently shape micro-behavior.

One of the key insights that results from a combination of Austrian economics and evolutionary economic geography is how entrepreneurship leads to the emergence of new industries. It is a process of entrepreneurial discovery, where the knowledge of 
one entrepreneur is combined with the knowledge of other actors. The knowledge is different enough to lead to a novel combination, but at the same time it involves actors that are not so different that they do not understand each other-we may call this "knowledge combination with an optimal cognitive distance" (cf. Nooteboom, 2000). Such combining of knowledge is more likely to occur among actors in spatial proximity than among distant actors, and it is especially likely to occur in places in which there is an abundance of actors with different prior knowledge (for example in cosmopolitan urban areas, or in highly diversified regional clusters; see Huber, forthcoming).

Such knowledge combinations take place before they trigger prices and market exchanges (the context of discovery), for example in entrepreneurial teams or through alliances of organizations. But markets play a key role in discovering the usefulness of these novel knowledge combinations (the context of justification), diffusing them beyond the initial locations of the respective combinations. Markets are thus instrumental in the rise of new industries (and the potential destruction of old ones). This will result in the growth of useful knowledge, with local origins and local applications, which entrepreneurial discovery connects to the market process.

\section{NOTES}

1 According to Kirzner (1997, p. 72), "[t]he notion of discovery, midway between that of deliberately produced information in standard search theory, and that of sheer windfall gain generated by pure chance, is central to the Austrian approach." In contrast, evolutionary economics focuses more heavily on chance, including chance

events (see Boschma and Lambooy, 1999). However, even chance "favors the 
prepared mind," and discovery is more likely to take place by actors with related knowledge (Nooteboom, 2000), so prior (localized) knowledge plays a role here as well (cf. Feldman and Francis, 2003).

2 This refers to uncertainty in the radical, Knightian sense (Knight, 1921), where no probability calculations with known expected outcomes apply.

3 On this abstract level, all people can be entrepreneurs; entrepreneurial behavior is a human universal; and the theory of entrepreneurship is a way of looking at all types of human action (Koppl, 2007; cf. Van Gelderen, 2000). However, one could argue that this perspective is more relevant in situations of uncertainty than in "mechanistic" predictable settings, and that certain psychological traits, for example an internal locus of control (see Harper, 1998), tend to make individuals more entrepreneurial (i.e., alert to entrepreneurial opportunities).

4 See Nooteboom (2000, pp. 96-99). Nooteboom argues that incentives for entrepreneurship constitute the ultimate cause of economic action.

5 In general, individuals respond to opportunities for higher pay elsewhere, but their sensitivity to this factor pales in comparison to their preference for living near family and friends, in Europe as well as in the United States (Dahl and Sorenson, 2010).

6 A strong science base is not a sufficient condition for an entrepreneurial region to arise. There are multiple regions where a strong scientific base has failed to spawn entrepreneurship (for example Ithaca (Cornell) and New Haven (Yale)). A study on 
new firm formation in the Netherlands (Bosma et al., 2007) was also unable to find a relation between the presence of a university and high levels of new firm formation. The authors explain this with a general lack of knowledge transfer from universities in the Netherlands.

7 Bettencourt et al. (2007a) show that larger metropolitan areas contain relatively many inventors (a super-linear relationship of inventors to population), while the productivity of individual inventors stays essentially constant across metropolitan areas. They also show that research and development establishments and employment in other creative professions follow super-linear scaling relations to metropolitan population size.

\section{REFERENCES}

Acemoglu, D. (1995). Reward structures and the allocation of talent. European Economic Review, 39(1), 17-33.

Acs, Z. J. and Armington, C. (2004). Employment growth and entrepreneurial activity in cities. Regional Studies, 38, 911-927.

Acs, Z. J., Bosma, N. S., and Sternberg, R. (2011). Entrepreneurship in world cities. In: M. Minniti (ed.), The Dynamics of Entrepreneurship. Oxford, UK: Oxford University Press.

Acs, Z. J., Braunerhjelm, P., Audretsch, D. B., and Carlsson, B. (2009). The knowledge spillover theory of entrepreneurship. Small Business Economics, 32(1), 15-30. 
Agarwal, R., Echambadi, R., Franco, A.M., and Sarkar, M.B. (2004), 'Knowledge transfer through inheritance: spin- out generation, development and survival, Academy of Management Journal, 47 (4), 501-22.

Aldrich, H. (1999). Organizations Evolving. London, UK: Sage.

Andersson, D. E. (2005). The Spatial Nature of Entrepreneurship. The Quarterly Journal of Austrian Economics, 8(2), 21-34.

Audia, P. G. and Rider, C. I. (2005). A Garage and an idea: What more does an entrepreneur need? California Management Review, 48, 6-28.

Audia, P. G. and Rider, C. I. (2006). Entrepreneurs as organizational products revisited. In: Baum, R., Frese, M., and Baron, R. (eds.), The Psychology of Entrepreneurship. Mahwah, NJ: Lawrence Erlbaum Associates, 113-130.

Audretsch, D. B. and Feldman M. P. (1996). R\&D spillovers and the geography of innovation and production. American Economic Review, 86, 630-640.

Audretsch, D. B., Keilbach, M. C., and Lehmann, E. (2006). Entrepreneurship and Economic Growth. Oxford, UK: Oxford University Press.

Audretsch, D. B. and Lehmann, E. (2005a). Do university policies make a difference? Research Policy, 34, 343-347.

Audretsch, D. B. and Lehmann, E. (2005b). Does the knowledge spillover theory of entrepreneurship hold for regions? Research Policy, 34, 1191-1202.

Audretsch, D. B., Lehmann, E., and Warning, S. (2005). University spillovers and new firm location. Research Policy, 34, 1113-1122.

Audretsch, D. B. and Stephan, P. E. (1996). Company-scientist locational links: The case of biotechnology. American Economic Review, 86(3), 641-652. 
Baum, J. A. C. and Mezias, S. J. (1992). Localized competition and organizational failure: The Manhattan hotel industry 1898-1990. Administrative Science Quarterly, 37, 580-604.

Baum, J. A. C. and Silverman, B. S. (2004). Picking winners or making them? Alliances, patents, and human capital as selection criteria in venture financing and performance of biotechnology startups. Journal of Business Venturing, 19, 411-436.

Baumol, W. J. (1990). Entrepreneurship: Productive, unproductive and destructive. Journal of Political Economy, 98, 893-921.

Bettencourt, L. M. A., Lobo, J., and Strumsky, D. (2007a). Invention in the city: Increasing returns to patenting as a scaling function of metropolitan size. Research Policy, 36, 107-120.

Bettencourt, L. M. A., Lobo, J., Helbing, D., Kuhnert, C., and West, G. B. (2007b). Growth, innovation, scaling, and the pace of life in cities. Proceedings of the National Academy of Sciences, 104(17), 7301-7306.

Beugelsdijk, S. (2007). Entrepreneurial culture, regional innovativeness and economic growth. Journal of Evolutionary Economics, 17(2), 187-210.

Blanchflower, D.G. and A.J. Oswald (1990) What makes a young entrepreneur? NBER working paper No. 3252.

Boettke, P. and Coyne, C. (2003). Entrepreneurship and development: Cause or consequence? Advances in Austrian Economics, 6, 67-88.

Boschma, R. A. and Frenken, K. (2006). Why is economic geography not an evolutionary science? Journal of Economic Geography, 6, 273-302.

Boschma, R. and Frenken, K. (2009). Some notes on institutions in evolutionary economic geography. Economic Geography, 85(2), 151-158. 
Boschma, R. A. and Lambooy, J. G. (1999). Evolutionary economics and economic geography. Journal of Evolutionary Economics, 9(4), 411-429.

Boschma, R.A. and Lambooy, J. G. (2000). The prospects of an adjustment policy based on collective learning in old industrial regions. GeoJournal, 49, 391399.

Boschma, R.A. and Martin, R.L. (eds.) (2010). The Handbook of Evolutionary Economic Geography. Cheltenham, UK: Edward Elgar.

Boschma, R.A. and Wenting, R. (2007). The spatial evolution of the British automobile industry. Does location matter? Industrial and Corporate Change, $16(2), 213-238$.

Bosma, N. and Schutjens, V. (2008). Mapping entrepreneurial activity and entrepreneurial attitudes in European regions. International Journal of Entrepreneurship and Small Business, 7(2), 191-213.

Bosma, N. S., Van Stel, A. J., and Suddle, K. (2007). The geography of new firm formation: Evidence from independent start-ups and new subsidiaries in the Netherlands. International Entrepreneurship and Management Journal, 4(2), $129-146$.

Brenner, T. and Fornahl, D. (2008). Regional path dependence in start-up activity. PEEG paper \#08.12, Urban and Regional Research Centre, Utrecht University, Utrecht.

Casper, S. (2007). Creating Silicon Valley in Europe: Public Policy towards New Technology Industries. Oxford, UK: Oxford University Press.

Cattani, G., Pennings, J. M., and Wezel, F. C. (2003). Spatial and temporal heterogeneity in founding patterns. Organization Science, 14(6), 670-685. 
Chandra, R. and Sandilands, R. J. (2005). Does modern endogenous growth theory adequately represent Allyn Young? Cambridge Journal of Economics, 29, 463-473.

Chesbrough, H. (1999). The differing organizational impact of technological change:

A comparative theory of national institutional factors. Industrial and Corporate Change, 8(3), 447-485.

Chinitz, B. (1961). Contrasts in agglomeration: New York and Pittsburgh. American Economic Review, 51(2), 279-289.

Cohen, W. M. and Levinthal, D. A. (1990). Absorptive capacity. Administrative Quarterly, 35, 128-153.

Cohen, W. M. and Malerba, F. (2001). Is the tendency to variation a chief cause of progress? Industrial and Corporate Change, 10(3), 587-607.

Cooper, A. C. and Folta, T. B. (2000). Entrepreneurship and high technology clusters. In: Sexton, D. L. and Landstrom, H. (eds.), Handbook of Entrepreneurship. Oxford, UK: Blackwell, 348-367.

Dahl, M. S. and Sorenson, O. (2010). The social attachment to place. Social Forces, 89, 633-658.

Dahl, M.S. and Sorenson, O. (2011) Home Sweet Home: Entrepreneurs' Location Choices and the Performance of Their Ventures. http://ssrn.com/abstract=1596810

Desrochers, P. (1998). A Geographical Perspective on Austrian Economics. The Quarterly Journal of Austrian Economics, 1(2), 63-83.

Dumais, G., Ellison, G. and Glaeser, E. L. (1997). Geographic concentration as a dynamic process. NBER Working Paper \#6270. 
Feldman, M. P. (2001). The entrepreneurial event revisited: Firm formation in a regional context. Industrial and Corporate Change, 10, 861-891.

Feldman, M. P. and Francis J. (2003). Fortune favors the prepared region: The case of entrepreneurship and the Capitol Region biotechnology cluster. European Planning Studies, 11, 765-788.

Figueiredo, O., Guimaraes, P., and Woodward, D. (2002). Home-field advantage: Location decisions of Portuguese entrepreneurs. Journal of Urban Economics, $52,341-361$

Frenken, K. and Boschma, R. A. (2007). A theoretical framework for evolutionary economic geography industrial dynamics and urban growth as branching processes. Journal of Economic Geography, 7(5), 635-649.

Fritsch, M. (2008). How does new business formation affect regional development? Introduction to the special issue. Small Business Economics, 30(1), 1-14.

Fuller, T. and Moran, P. (2001). Small enterprises as complex adaptive systems: A methodological question? Entrepreneurship and Regional Development, $13(1), 47-63$.

Garnsey, E. and Heffernan P. (2005). High tech clustering through spin out and attraction; the Cambridge case. Regional Studies, 39(8), 1127-1144.

Giannetti, M. and Simonov, A. (2009). Social interactions and entrepreneurial activity. Journal of Economics \& Management Strategy, 18(3), 665-709.

Glaeser, E. L. (1999). Learning in cities. Journal of Urban Economics. 46, 254-277.

Glaeser, E. L., Kolko, J., and Saiz, A. (2000). Consumer city. Journal of Economic Geography, 1(1), 27-50.

Glaeser, E. L. (2007). Entrepreneurship and the city. NBER Working Paper No. W13551. 
Glaeser, E. L. and Gottlieb, J. D. (2006). Urban resurgence and the consumer city. Urban Studies, 43(8), 1275-1299.

Gompers, P., J. Lerner and D. Scharfstein (2005), 'Entrepreneurial spawning: public corporations and the formation of new ventures, 1986-1999', Journal of Finance, 60, 577-614.

Grebel, T, Pyka, A., and Hanusch, H. (2003). An evolutionary approach to the theory of the entrepreneur. Industry and Innovation, 10, 493-514.

Hall, P. (1998). Cities in Civilization. New York, NY: Pantheon Books.

Hannan, M. T., Carroll, G. R., Dundon, E. A., and Torres, J. C. (1995). Organizational evolution in multinational context: Entries of automobile manufacturers in Belgium, Britain, France, Germany and Italy. American Sociological Review, 60(4), 509-528.

Harper, D. (1996). Entrepreneurship and the Market Process: An Inquiry into the Growth of Knowledge. London, UK: Routledge.

Harper, D. (1998). Institutional conditions for entrepreneurship. Advances in Austrian Economics, 5, 241-275.

Hayek, F. A., (1945). The use of knowledge in society. American Economic Review, $35(4), 1-11$.

Hayek, F. A. (1967). Studies in Philosophy, Politics, and Economics. Chicago, IL: University of Chicago Press.

Hayek, F. A. (1978). New Studies in Philosophy, Politics, Economics, and the History of Ideas. London, UK: Routledge and Kegan Paul.

Heijman, W. J. M. and Leen, A. R. (2004) On Austrian regional economics. Papers in Regional Science, 83, 487-493. 
Hidalgo, C. and Hausmann, R. (2009). The building blocks of economic complexity. Proceedings of the National Academy of Sciences, 106, 10570-10575

Hirooka, M. (2006). Innovation Dynamism and Economic Growth. Cheltenham, UK: Edward Elgar.

Holcombe, R. G. (2007). Entrepreneurship and Economic Growth. In: Powell, B. (ed.), Making Poor Nations Rich: Entrepreneurship and the Process of Economic Development. Stanford, CA: Stanford University Press.

Hoover, E. M. and Vernon, R. (1959). Anatomy of a Metropolis. Cambridge, MA: Harvard University Press.

Huber, F. (forthcoming). On the role and interrelationship of spatial, social and cognitive proximity: Personal knowledge relationships of $R \& D$ workers in the Cambridge information technology cluster. Regional Studies.

Jacobs, J. (1961). The Death and Life of Great American Cities. New York, NY: Vintage Books.

Jacobs, J. (1969). The Economy of Cities. New York, NY: Vintage Books.

Jacobs, J. (1984). Cities and the Wealth of Nations. New York, NY: Vintage Books.

Keeble, D., Lawson, C., Moore, B., and Wilkinson, F. (1999). Collective learning processes, networking and 'institutional thickness' in the Cambridge region. Regional Studies, 33(4), 319-332.

Kenney, M. and Von Burg, U. (1999). Technology and path dependence: The divergence between Silicon Valley and Route 128. Industrial and Corporate Change, 8(1), 67-103.

Kirchhoff, B. A., Newbert, S. L., Hasan, I., and Armington, C. (2007). The influence of university $R \& D$ expenditures on new business formations and employment growth. Entrepreneurship Theory and Practice, 31(4), 543-559. 
Kirzner, I. M. (1997). Entrepreneurial discovery and the competitive market process: An Austrian approach. Journal of Economic Literature, 35, 60-85.

Klepper, S. (2001). Employee startups in high-tech industries. Industrial and Corporate Change, 10(3), 639-674.

Klepper, S. (2002). The capabilities of new firms and the evolution of the US automobile industry. Industrial and Corporate Change, 11(4), 645-666.

Klepper, S. (2007). Disagreements, spinoffs, and the evolution of Detroit as the capital of the U.S. automobile industry. Management Science, 53, 616-631.

Klepper, S. (2009). Spinoffs: A review and synthesis. European Management Review, $6,159-171$

Klepper, S. (2010). The origin and growth of industry clusters: The making of Silicon Valley and Detroit. Journal of Urban Economics, 67(1), 15-32.

Klepper, S. (2011). Nano-economics, spinoffs, and the wealth of regions. Small Business Economics, 37, 141-154.

Knight, F. H. (1921). Risk, Uncertainty and Profit. Boston, MA: Hart, Schaffner \& Marx.

Koppl, R. (2006). Austrian economics at the cutting edge. Review of Austrian Economics, 19(4), 231-241.

Koppl, R. (2007). Entrepreneurial behavior as a human universal. In: Zacharakis, A., Minniti, M., Spinelli, S., Rice, M. P., and Habbershon, T. G. (eds.), Entrepreneurship: The Engine of Growth (Volume 1). Westport, CT: Greenwood Publishing Group, 1-20.

Kreft, S. F. and Sobel, R. S. (2005). Public policy, entrepreneurship, and economic growth. Cato Journal, 25(3), 595-616. 
Krugman, P. (1995). Geography, Trade and Development. Cambridge, MA: MIT Press.

Lachmann, L. (1978). An Austrian stocktaking: Unsettled questions and tentative answers. In: Spadaro, L. (ed.), New Directions in Austrian Economics. Kansas City, MO: Sheed, Andrews \& McMeel, 1-18.

Lambooy, J. G. (1998). Agglomeration Economies: Cities in the Knowledge Economy. Utrecht: Utrecht University.

Lambooy, J. G. (2010a). Knowledge transfers, spillovers and actors. European Planning Studies, 18(6), 873-891.

Lambooy, J. G. (2010b). The evolution of spatial patterns over long time-horizons. In: Boschma, R.A. and Martin, R. (eds.), The Handbook of Evolutionary Economic Geography. Cheltenham, UK: Edward Elgar, 471-486.

Lambooy, J. G. and Boschma, R. A. (2001). Evolutionary economics and regional policy. Annals of Regional Science, 35(1), 113-133.

Maggioni, M. A. (2006). Mors tua, vita mea? The rise and fall of innovative industrial clusters. In: Braunerhjelm, P. and Feldman, M. (eds.), Cluster Genesis. Oxford, UK: Oxford University Press, 219-242.

Marshall, A. (1890). Principles of Economics. London, UK: Macmillan.

Martin, R. and Sunley P. (1998). Slow convergence? The new endogenous growth theory and regional development. Economic Geography, 74, 201-227.

Martin, R. and Sunley, P. (2007). Complexity thinking and evolutionary economic geography. Journal of Economic Geography, 7(5), 573-601.

Metcalfe, J. S. (2002). Knowledge of growth and the growth of knowledge. Journal of Evolutionary Economics, 12(1-2), 3-15. 
Metcalfe, J. S. (2004). The entrepreneur and the style of modern economics. Journal of Evolutionary Economics, 14(2), 157-175.

Michelacci, C. and Silva, O. (2007). Why so many local entrepreneurs? Review of Economics and Statistics, 89(4), 615-633.

Moore, G. and Davis, K. (2004). Learning the Silicon Valley way. In: Bresnahan, T. and Gambardella, A. (eds.), Building High-Tech Clusters: Silicon Valley and Beyond. Cambridge University Press, UK: Cambridge, 7-39.

Murphy, K. M., Shleifer, A., and Vishny, R. W. (1991). The allocation of talent: Implications for growth. Quarterly Journal of Economics, 106, 503-530.

Nooteboom, B. (2000). Learning and Innovation in Organizations and Economics. Oxford, UK: Oxford University Press.

O'Farrell, P. N. and Crouchley, R. (1984). An industrial and spatial analysis of new firm formation in Ireland. Regional Studies, 18, 221-236.

Orsenigo, L. (2006). Clusters and clustering: Stylized facts, issues, and theories. In: Braunerhjelm, P. and Feldman, M. (eds.), Cluster Genesis: Technology-based Industrial Development. Oxford, UK: Oxford University Press, 195-218.

Parwada, J. T. (2008). The genesis of home bias? The location and portfolio choices of investment company start-ups. Journal of Financial and Quantitative Analysis, 43, 245-266.

Piore, M. J. and Sabel, C. F. (1984). Second Industrial Divide: Possibilities for Prosperity. New York, NY: Basic Books.

Reynolds, P., Storey, D. J., and Westhead, P. (1994). Cross-national comparisons of the variation in new firm formation rates. Regional Studies, 28, 443-456.

Reynolds, P. D. and White, S. B. (1997). The Entrepreneurial Process: Economic Growth, Men, Women, and Minorities. Westport, CT: Quorum Books. 
Saxenian, A. (1994). Regional Advantage: Culture and Competition in Silicon Valley and Route 128. Cambridge, MA: Harvard University Press.

Saxenian, A. (2006). The New Argonauts: Regional Advantage in a Global Economy. Cambridge, MA: Harvard University Press.

Schumpeter, J. A. (1934). The Theory of Economic Development. Cambridge, MA: Harvard University Press.

Shane, S. (2000). Prior knowledge and the discovery of entrepreneurial opportunities. Organization Science, 11, 448-469.

Sorensen, O. (2003). Social networks and industrial geography. Journal of Evolutionary Economics, 13, 513-527.

Sorenson, O. and Audia, P.G. (2000). The social structure of entrepreneurial activity: Geographic production of footwear in the United States, 1940-1989. American Journal of Sociology, 106: 1546-1588.

Stam, E. (2005). The geography of gazelles in the Netherlands. Tijdschrift voor Economische en Sociale Geografie, 96(1), 121-127.

Stam, E. (2007). Why butterflies don't leave. Economic Geography, 83, 27-50.

Stam, E. (2010). Entrepreneurship, evolution and geography. In: Boschma, R. and Martin, R. L. (eds.), The Handbook of Evolutionary Economic Geography. Cheltenham, UK: Edward Elgar, 307-348.

Stam, E. and Wennberg, K. (2009). The roles of R\&D in new firm growth. Small Business Economics, 33(1), 77-89.

Storey, D. J. (1982). Entrepreneurship and the New Firm. London, UK: Croom Helm. Storper, M. (2011). Why do regions develop and change? The challenge for geography and economics. Journal of Economic Geography, 11, 333-346. 
Stuart, T. E. and Sorenson, O. (2003). The geography of opportunity: Spatial heterogeneity in founding rates and the performance of biotechnology firms. Research Policy, 32, 229-253.

Swedberg, R. (2000). Entrepreneurship - The Social Science View. Oxford, UK: Oxford University Press.

Young, A. (1928). Increasing returns and economic progress. Economic Journal, 38, 527-542.

Van Gelderen, M. (2000). Enterprising behaviour of ordinary people. European Journal of Work and Organizational Psychology, 9(1), 81-88.

Van Wissen, L. (2004). A spatial interpretation of the density dependence model in industrial demography. Small Business Economics, 22(3-4), 253-264.

Wagner, J. and Sternberg, R. (2004). Start-up activities, individual characteristics, and the regional milieu: Lessons for entrepreneurship support policies from German micro data. Annals of Regional Science, 38, 219-240.

Wenting, R. (2008). Spinoff dynamics and the spatial formation of the fashion design industry, 1858-2005. Journal of Economic Geography, 8, 593-614.

Witt, U. (1998). Imagination and leadership-The neglected dimension of an evolutionary theory of the firm. Journal of Economic Behavior and Organization, 35(2), 161-177.

Zucker, L. G., Darby, M. R., and Brewer, M. B. (1998). Intellectual human capital and the birth of U.S. biotechnology enterprises. American Economic Review, 88, 290-306. 